Douglas B. Craig MD FRCP(C), Deepak Bose MD PHD

\title{
Drug interactions in anaesthesia: chronic antihypertensive therapy
}

Three factors have combined to increase the need for the anaesthetist to be aware of potential drug interactions involving chronic antihypertensive therapy. First is the emphasis on early recognition and treatment of hypertensives, with the result that more patients are receiving antihypertensive therapy. Second is the introduction of a wide variety of potent medications to the therapy of chronic hypertension. Third is the realisation that, in contrast to earlier recommendations, most antihypertensive agents should be continued up to and including the day of surgery and in some instances should be administered during the anaesthetic. The result of this combination of factors is the presentation for surgery of increasing numbers of patients taking more and more complicated drugs, which remain active during anaesthesia and surgery, thereby creating the potential for drug interactions.

This review will present an overview of the agents currently used to treat chronic hypertension and will examine their known or predicted interactions of interest to the anaesthetist.

\section{Etiology of hypertension}

The general topic of hypertension and anaesthesia was the subject of a recent review in this journal.' Approximately 85 per cent of hypertensive patients have primary (essential) hypertension, where no specific cause can be identified. The majority of these patients ( 70 per cent) have low or normal plasma renin activity while the minority (15 per cent) have increased activity. ${ }^{2}$

In the remaining 15 per cent of patients where the hypertension is secondary to identifiable causes, renal diseasc (parenchymal or vascular) is the dominant factor. The anaesthestic implications of chronic renal disease have also recently been reviewed in this journal. ${ }^{3}$

Endocrinological causes of hypertension (e.g., primary aldosteronism, pheochromocytoma, Cush- ing 's disense) will not be discussed. Less than one per cent of hypertensive patients fall within this category.

\section{Spectrum of drug therapy}

Drugs employed in the treatment of chronic hypertensive patients range from the sedative/hypnotics and tranquilizers to agents with specific and direct cardiovascular activily. Combination therapy in hypertension, involving either drugs within the same therapeutic group or different groups has become common. This review will include diuretics, vasodilators, drugs influencing adrenergic transmission (adrenergic neurone blocking agents, drugs causing centrally mediated adrenergic inhibition, alpha and beta adrenergic receptor antagonists, monoamine oxidase inhibitors) and inhibitors of angiotensin-converting enzyme and angiotensin. The discussion of each drug category will include : brief examination of the mechanism of action of the specific drugs, followed by a summary of their knowr. or predicted drug interactions.

\section{Anaesthetic implications}

Potential anaesthetic implications of chronic antihypertensive therapy fall into two categories. First is the interference with homeostatic mechanisms

From the Departments of Anesthesia and Pharmacology \& Therapeutics, Faculty of Medicine, University of Manitoba.

Address correspondence to: Dr. Douglas B. Craig, Dept. of Anaesthesia, Health Sciences Centre, Room LB-315, 700 William Avenue, Winnipeg, Manitoba, R3E 0Z3.

Adapted from "Manual of Drug Interactions in Anesthesia" by Douglas B. Craig MD and Deepak Bose MD PH D, to be published by Churchill Livingstone Inc. Used by permission. 
TABLE 1 Diuretics

\begin{tabular}{|c|c|c|}
\hline GenericiTrade names & Problems/Interactions & Comments \\
\hline 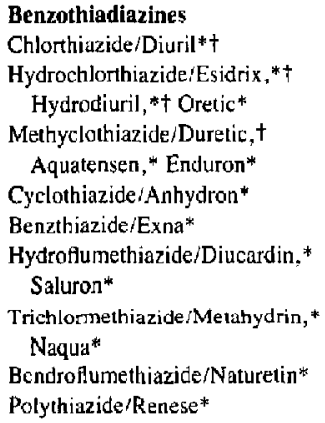 & $\begin{array}{l}\text { Potential exaggerated hypotensive effect of } \\
\text { anaesthetic agents (inhaled and injected) } \\
\text { Increased incidence of ectopic pacemaker } \\
\text { activity and myocardial conduction } \\
\text { defects. (Premature ventricular } \\
\text { contractions) } \\
\text { Potentiation of action of non-depolarizing } \\
\text { neuromuscular blocking agents } \\
\text { Additive effects with antilypertensive } \\
\text { medications } \\
\text { Weak diabetogenic action }\end{array}$ & $\begin{array}{l}\text { Hypokalemia common. Monitor serum } \mathrm{K}^{-} \text {. } \\
\text { Supplementation may be indicated before } \\
\text { surgery } \\
\text { Therapeutically useful cffect } \\
\text { Monitor effects }\end{array}$ \\
\hline Chlorthalidone/Hygroton* & Decreased uric acid excretion & $\begin{array}{l}\text { May precipitate or worsen gout, particularly } \\
\text { during and following anaesthesia when } \\
\text { uric acid excretion is reduced. Adjust } \\
\text { management/substitute a termate diuretic }\end{array}$ \\
\hline $\begin{array}{l}\text { Loop diuretics } \\
\text { Furesemide/Lasix, }{ }^{* \dagger} \text { Uritrol† } \\
\text { Ethacrynic Acid/Edecrin*† }\end{array}$ & $\begin{array}{l}\text { Similar effects as benzothiadiazines re: } \\
\text { - Hypovolemia } \\
\text { - Additive effects with antihypertensives } \\
\text { Altered ( } \uparrow \text { or } \downarrow \text { ) anti-coagulant } \\
\text { effect of Warfarin } \\
\text { Potential lithium toxicity during concomitant } \\
\text { therapy }\end{array}$ & $\begin{array}{l}\text { Mechanism unknown. Monilor coagulation } \\
\text { status } \\
\text { Increased tubular reabsorption of lithium. } \\
\text { Monitor levels/adjust dose }\end{array}$ \\
\hline $\begin{array}{l}\text { Distal tubule diuretics } \\
\text { Spironolactone/Aldactone* } \dagger\end{array}$ & Potential for hyperkalemia & erone anlagonist. Monitor serum $\mathrm{K}^{+}$, \\
\hline Triamterene:Dyrenium ${ }^{* \dagger}$ & Potential for hyperkalemia & $\begin{array}{l}\text { Distal sodium reabsorplion blocked directly } \\
\text { but } \mathrm{K}^{+} \text {spared. Monitor serum } \mathrm{K}^{+} \text {. Awoid } \\
\mathrm{K}^{+} \text {supplements }\end{array}$ \\
\hline
\end{tabular}

*USA.

†Canada.

necessary to maintain cardiovasculat stability during the perioperative period. This potential is shared, to varying degrees, by most antihypertensive medications. Second are actual direct interactions or potential interactions.

Responses to cardiovaseular depressant drugs, blood and fluid losses, positioning, and positive pressure ventilation can be conveniently viewed as requiring an intact sympathetic nervous system with a responsive heart and peripheral vasculature. Interference by drugs at any level in the sympathctic nervous system or in the cardiovascular system may impair the required homeostatic response. The discussion which follows will identify the presumed sites of interference with normal homeostatic responses.

\section{Diuretics}

Although antihypertensive agents with relatively selective sites or mechanisms of action are now available, diuretics have remained part of the first line treatment of hypertension. Table I lists diuretics currently employed in the treatment of hypertension. In spite of different chemical structures and sites of action in the kidney, their primary antihypertensive mechanism is natiuresis. The acutc effects of diuretics include a decrease in extracellular fluid volume and cardiac output with an accompanying increase in systemic vascular resistance. With time, and maintenance of a natiuresis, the blood volume returns toward normal and the predominent remaining effect is decreased vascular resistance. ${ }^{2,4}$ 
In addition to the potential for hypovolemia, the effects of diuretics most relevant for the anaesthetist are their influence on potassium balance. With the exception of agents acting on the distal tubule (Table 1), which have the potential to produce hyperkalamia, other diuretics tend to produce hypokalemia. Although moderate chronic hypokelamia is normally well tolerated, circumstances during anaesthesia and surgery may tend to superimpose an acute reduction in extracellular potassium. Such circumstances include the rapid intracellular shifts produced by respiratory alkalosis or glucose administration as well as acute loss of potassium from the body due to administration of diuretics such as mannitol or acelazolamide.

\section{Drugs influencing adrenergic transmission}

In order to understand the actions and potential interactions of drugs within this classification, it is necessary to review the physiology of the sympathetic nervous system. It is convenient to focus directly on the peripheral sympathetic nervous system, without considering central sympathetic nuclei, central sympathecic pathways or the sympathetic ganglia.

The functional unit of the peripheral sympathetic

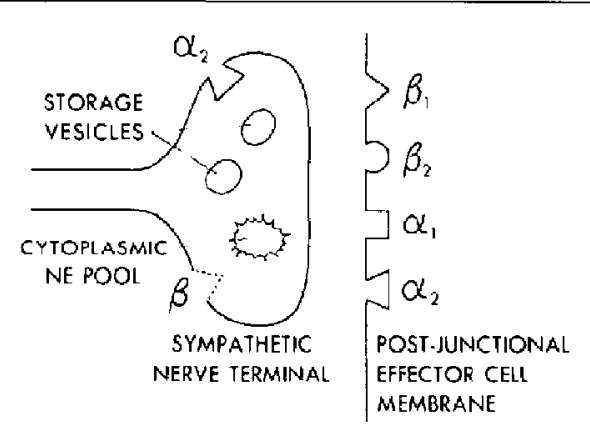

FIGURE I Sympathetic nerve lerminal with adjacent elfector cell. Receptor differentiation is based on observed responses to various agonists and antagonists. See text for details. Nerve action potential releases NE by exocytosis of storage granules. Granules extrude their contents (NE, dopaminc, dopamine beta hydroxylase) into synaptic cleft atter they fuse with the nerve membrane. Indirectly acling symparhominetics cause displace ment of NE from the storage granules into the cytoplasmic pool, from which they are released. No fusion of granule with membrane occurs. Presynaptic beta receptor stimulation promotes NE releuse. Presynaptic alpha ${ }_{2}$ receptor stimulation inhibits NE release. Some alphi $\mathrm{i}_{2}$ receptors are postsynaptic.

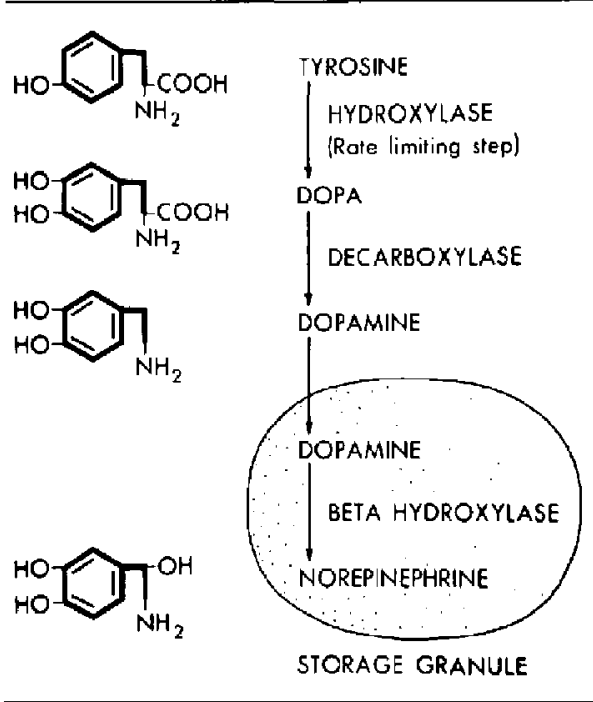

FIGURE 2 Synthesis pathway of norepinephrine (NE) within sympathetic nerve terminal. Tyrosine enters nerve terminal from the circulation. Note that step from tyrosine to dopa, calalyzed by the enzyme tyrosine hydroxylase is rate limiting. Inhibition of this enzyme should decrease the rate of NE synthesis. Inhibition of the other enzymes in the pathway would be expected to have no influence on the rate of NE synthesis.

nervous system is the nerve terminal at the end of the sympathetic post-ganglionic nerve and the adjacent adrenergic receptors, located across the synaptic cleft or in the nerve terminal (Fig. 1). Norepinephrine is synthesized in the nerve terminal by a number of enzyme-mediated steps (Fig. 2) which are susceptible to substrate substitution or enzyme inhibition, by exogenous drugs. The final steps in NE synthesis occur in storage granules within the nerve terminal. A nerve action potential along the sympathetic nerve induces release of $\mathrm{NE}$ by exocytosis from the storage granules; the NE then acts on the adjacent receptors. A small pool of $\mathrm{NE}$ is also present within the cytoplasm of the nerve terminal, but outside of the granules, representing NE released from storage granules by drugs, or taken up from the synaptic cleft by the amine re-uptake process.

Alpha adrenergic receptors are subdivided into alpha, receptors (postsynaptic) which are excitatory and alpha $a_{2}$ receptors (mainly presynaptic) which are inhibitory (Fig. 1). In the peripheral sympathetic nervous system some of the released NE stimulates 
presynaptic alpha $\mathrm{a}_{2}$ receptors, resulting in reduced NE release.

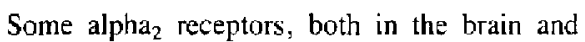
elsewhere are postsynaptic. ${ }^{3}$ Stimulation of CNS alpha ${ }_{2}$ receptors causes decreased sympathetic outHow to the periphery. This distinction between

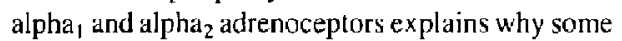
adrenergic agonists [e.g., clonidine (Table II) which is principally an alpha 2 agonist in the CNS and periphery primarily cause decreased sympathetic activity in the periphery.

Beta adrenergic receptors are divided into beta,

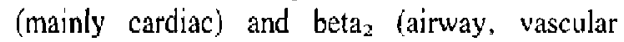
smooth muscle, and other). Stimulation of presynaptic beta receptors (Fig. 1) enhances NE release, but the physiological importance of this action has not been established.

Although the role of presynaptic receptors remains to be firmly established, knowledge of their presence improves the understanding of various drug actions and interactions.

A third type of adrenergic receptor, "specific" for dopamine, is located in cerebral, coronary, renal and mesenteric vessels. Dopaminergic receptor stimulation produces vasodilation. Dopamine is the immediate metabolic precursor of NE (Fig. 2) and is also a central neurotransmitter. Dopamine releases $\mathrm{NE}$, and also directly stimulates dopaminergic, alpha and beta receptors, the net effect depending principally on the dose administered.

Termination of NE action is mainly by re-uptake, first across the nerve cell membrane into the nerve terminal where it forms a small cytoplasmic pool of $\mathrm{NE}$ and then into the storage granules. A minor portion of the released NE is metabolized, by monoamine oxidase (MAO) within the nerve terminal (Inainly), when the rate of release is slow or when release is induced from the granules by indirectly acting sympathomimetics (e.g., ephedrine, tyramine). The metabolite of MAO action on $\mathrm{NE}$, and circulating NE itself are acted on subsequently by catechol-o-methyl transferase (COMT) in the innervated tissue and the liver. Rapidly released NE is primarily degraded by COMT. Drugs which block neuronal reuptake of NE increase its effectiveness on postsynaptic receptors. more than do drugs which bluck degradative enzymes. Paradoxically, MAO inhibitors reduce sympathetic neuronal outflow by feedback inhibition of NE synthesis and by formation of false transmitters (e.g., octopamine) which have less pressor activity than NE (see below).

An understanding of drug actions and potential interactions requires, therefore, consideration of each of the steps outlined above: NE synthesis, NE storage, NE release, receptor activation, NE reuptake, NE metabolism.

\section{Adrenergic neurone inhibitors}

Reserpine, when used in large doses as a major tranquilizer or as an antihypertensive, has the potential to produce significant and refractory hypotension during anaesthesia (Table 11). However, the current use of this agent in very small doses, and usually in combination with other antihypertensive agents, greatly reduces the potential for drug interactions.

Debrisoquine, in addition to the primary mechanisms noted in Table II, has MAO inhibitory effects in vitro. The product information for debrisoquine ${ }^{7}$ contains the following statement: "To avoid the possibility of vascular coliapse, discontinuc debrisoquine 24 hours prior to elective surgery. "Communication with the manufacturer* and with the Health Protection Branch, Health and Welfare Canadat indicated that direct information supporting this recommendation was not available. Clinical experience suggests that debrisoquine can be safely continued until the time of surgery.

\section{Centrally mediuted adrenergic inhibitors}

Clonidine, and alpha methyl norepinephrine (an active metabolite of methyldopa) appear to produce their primary antihypertensive effect through central alpha $a_{2}$ adrenergic receptor stimulation. Although Figure I illustrates a peripheral sympathetic nerve terminal, similar principles apply concerning the inhibitory effects of central postsynaptic alpha. receptor stimulation. Clonidine is an alpha, and alpha $_{2}$ agonist but the alpha (inhibitory) effect dominates with time. It was previously thought that alpha methyl NE was a false transmitter in the periphery. This is not the likely antihypertensive mechanism. Alpha methy] NE is stored and released in a fashion similar to NE but is less active

"Personal communication: Dr. S.G. McKenzic, Hoffmann-LaRoche Ltd., Vaudreuil, Québec.

$\uparrow$ Personal conmunicution: Dr. B.A. Kovacs, Health and Welfare Canada, Ottawa, Ontario. 
TABLE If Drugs influencing adrenergic transmission

\begin{tabular}{|c|c|c|}
\hline Generic/Trade names & Problems/Inteructions & Conments \\
\hline \multicolumn{3}{|c|}{ Adrenerglc neurone blocking agents } \\
\hline \multirow{5}{*}{$\begin{array}{l}\text { Reserpine/Serpasil }{ }^{* \dagger} \\
\text { Reserfia, }+ \text { Novoreserpine } \dagger\end{array}$} & ] Potential exaggerated hypotensive & Depleted NE stores duc to block of \\
\hline & $\begin{array}{l}\text { response to anacsthetics (inhaled and } \\
\text { injected), hypovolemia, positive } \\
\text { airway pressures, sympathetic } \\
\text { blockade (c.g., spinal anaesthesia) }\end{array}$ & $\begin{array}{l}\text { reuptake into vesicles. Reduced } \\
\text { sympathetic activity'response. } \\
\text { Reduce/titrate doses of depressants. } \\
\text { Maintain blood volume }\end{array}$ \\
\hline & $\begin{array}{l}2 \text { Possible reduced response to indirectly } \\
\text { acting vasopressors }\end{array}$ & $\begin{array}{l}\text { Reduced NE available for release. Titrite } \\
\text { doses. Consider directly acting agents } \\
\text { (see \#3) }\end{array}$ \\
\hline & $\begin{array}{l}3 \text { lncreased response to directly acting } \\
\text { vasopressors }\end{array}$ & $\begin{array}{l}\text { Alpha, receptors sensitive due to chronic } \\
\text { NE deprivation. Usc reduced ititrated } \\
\text { doses of direct alpha agonists }\end{array}$ \\
\hline & $\begin{array}{l}4 \text { Reduced MAC for halothane (dogs). } \\
\text { Presumed similar in humans }\end{array}$ & Assumed brain amine depletion \\
\hline Guanethidine/lsmelin*广- & $\begin{array}{l}\text { Similar to items 1, 2, } 3 \text { above. MAC not } \\
\text { affected }\end{array}$ & $\begin{array}{l}\text { Displaces NE from vesicles in nerve } \\
\text { terminal. Reduces NE stores } \\
\text { Does not cross blood-brain barrier }\end{array}$ \\
\hline Debrisoquine/Declinax $\not$ & Similat to items $1,2,3$ above & $\begin{array}{l}\text { Displaces NE fronm vesicles in nerve } \\
\text { terminal. Reduces NE stores. Also } \\
\text { MAOL action, but unlikely of clinical } \\
\text { significance }\end{array}$ \\
\hline
\end{tabular}

Centrally mediated adrencrgic inhibitors

Methyl Dopa/Aldomet. *† Dopamet, ${ }^{+}$Similar to items 1-4 above (reserpine)

Medimet, $†$ Novomedopa $†$

Clonidine/Catapres, ${ }^{* \dagger}$ Dixar.t†

Monoamine-oxidase inhibitor

Pargyline/Eutonyl*

\section{Reduces therapeutic effect of L-dopa}

Potential additive effect with other hypotensive agents/events.

Hypertensive effecl if rapidly administered IV

Possible rebound hypertension following abrupl withdrawal

Exaggerated hypotensive response (see Reserpine item 1 above)

Exaggerated hypertensive response to indirectly acting vasopressors (e.g., epheprine)

Adverse response (coma, pyrexia, hypoi hypertension possible with meperidine/Demerol* $\dagger$

Multiple other drug interactions possible
Reduced sympathetic activity mainly due to central alpha ${ }_{2}$ stimulation by alpha. methyl NE (formed from methyldopa)

Alphamethyl NE acts as partial agonist peripherally (less important)

Methyl dopa inhibiss dopa-decarboxylase. Avoid combination

Central alpha, stimulation, reduccd sympathetic activity (peripheral NE slores normal)

Initial alpha, stimulation dominates (IV admin).

Short elimination half-life. Persistence of compensallury mechanisms which increase sympathetic activily. Inadequate time for readjustment. Withdraw slowly or substitute alternate antihypertensive agent

Decreased NE available for release from vesicles. See text and Fig. 3.

Discontinue prior to anaesthesia.

Excess NE available fọr release from sytoplasmic NE pool. See text and Fig. 4

Mechanism unknown. Avoid combinution

Anticipate possible adverse effects/ interactions. Consult general drug interaction sources. . $^{16,17}$ 
TABLE II Continued

\begin{tabular}{|c|c|c|}
\hline GenericiTrade names & Problemsilnteractions & Comments \\
\hline 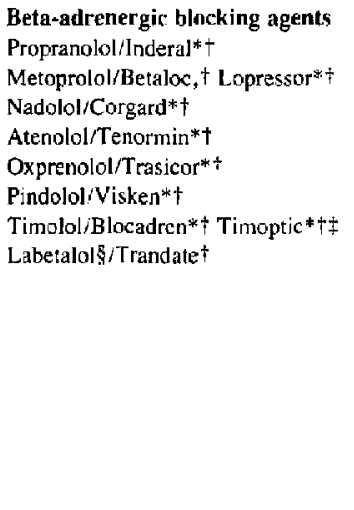 & $\begin{array}{l}\text { (Most ayailable information is for } \\
\text { propranolol. Conformity of other } \\
\text { agents has not been established) } \\
\text { Added myocardial depressant effect with } \\
\text { inhalation anaesthetics } \\
\text { Predicted impaired compensation } \\
\text { (increased heart rate) for hypovolemia } \\
\text { Possible rebound increase in sympathetic } \\
\text { activity after abrupt withdrawal } \\
\text { Possible bronchospasm, cardiac failure, } \\
\text { metabolic disturbances }\end{array}$ & $\begin{array}{l}\text { See text - reduce/titrate dose of inhalation } \\
\text { agent. Use combination with caution } \\
\text { Not substantiated by clinical reports, but } \\
\text { remains of concem } \\
\text { Appears related to receptor induction and } \\
\text { to short elimination half-life (e.g., } \\
\text { propranolol, see Table III) with } \\
\text { inadequate time for adjustment. With- } \\
\text { draw slowly. Predicted less problem } \\
\text { with longer acting agents (e.g., } \\
\text { nadolol) } \\
\text { Direct result of beta blocking effects }\end{array}$ \\
\hline
\end{tabular}

*USA.

$\leftarrow$ Canada.

tOphthalmic solution - systemic effects possible.

$\$$ Also has alpha adrenergic blocking properties.

than NE. However, the primary antihypertensive effect appears to be the pronounced central alpha receptor stimulation, as with clonidine. The inhibjtion of dopa decarboxylase by methyldopa does not affect NE synthesis, as this step is not rate limiting (Fig. 2).

Of particular concern is the possibility of rebound hypertension following abrupt withdrawal of clonidine. This can be avoided by continuation of the agent up to the time of surgery and its early resumption ot, alternately, substitution of another agent or agents several days before surgery.

\section{Monoamine axidase inhibitor (MAOI)}

Pargyline (Eutonyl) is available in the United States as an antihypertensive agent but fortunately is very rarely used. Anaesthetists, however, must recognize the possibility that patients may be receiving this agent for hypertension. As summarized in Figure 3 , chronic MAOI therapy leads to reduced endogenous sympathetic activity due to the presence of the tyramine metabolite octopamine, a false transmitter, within storage vesicles and reduced NE synthesis due to increased cytoplasmic NE stores, which produce inhibition of tyrosine hydroxylase.
The potential exists for indirectly acting vasopressors (e.g., tyramine) which are inactivated by MAO to have an exaggerated effect through increased release of the endogenous NE stores (Fig. 4). Most agree that MAOIs should be discontinued at least two weeks prior to elective surgery. An appropriate alternate agent should be substituted. Management

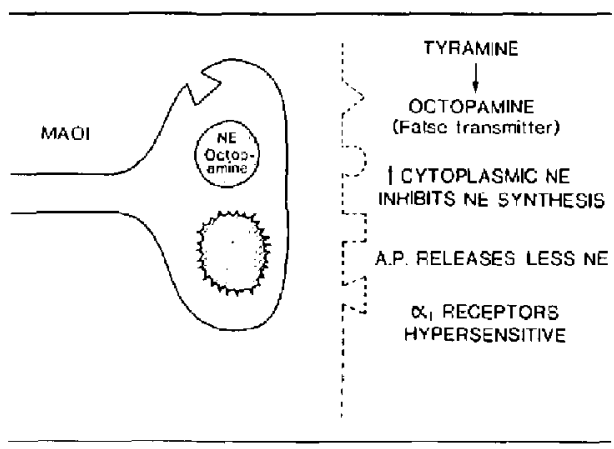

FIGURE 3 Summary of effects of chronic MAOI therapy on sympathetic nerve terminal and adjacent receptors. Intragranular NE is reduced while cytoplasmic NE is increased. Action potential-induced NE release (see Fig. 1) produces less NE than normal. 


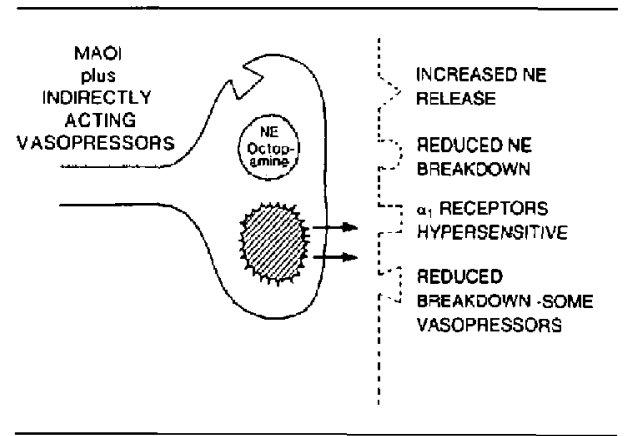

FIGURE 4 Summary of results of administration of indirectly acting vasopressors to patients chronically receiving $\mathrm{MAOl}_{5}$ Increased amounts of $\mathrm{NE}$ are released from the granules and from the enlarged cytoplasmic pool (not by exocytosis - see Eig. 1). Breakdown of tyraminc is reduced. (Ephedrine is not Inetabolised by MAO.)

of patients requiring emergency surgety and who are taking a MAOI should include special monitoring, use of reduced and titrated doses of anaesthetic agents, avoidance of indirectly acting vasopressors and of meperidine and morphine, and immediate ability to treat both hypotensive and hypertensive reactions. Small and carefully titrated doses of a directly acting adrenergic agonist (e.g., phenylephrine) is suggested for hypotension refractory to other measures while hypertensive crises related to excess norepinephrine release can be treated by an alpha adrenergic blocker (phentolamine/Regitine (USA), Rogitine (Canada)) or a direct vascular smooth muscle relaxant (e.g., nitroprusside/ Nipride).

\section{Beta adrenergic reccptor antagonists}

A large number of beta blockers are currently available in North America. ${ }^{9,10}$ Table III lists currently available agents and their properties. Potential interactions are listed in Table II. An earlier concern about the potential of beta blockers (propanolol) to produce major myocardial depression when used in combination with inhalation anaesthetics has been replaced by the conclusion that beta blockers should be continued up to the time of surgery and possibly during surgery. Inhalation agents demonstrated to be compatible with beta blockade (isoflurane, cnflurane, halothane) can be administered in carefully adjusted, reduced doses. ${ }^{11,12}$
TABLE III Beta adrenergic receptor-blockers

\begin{tabular}{llll}
\hline Agent* & $\begin{array}{l}\text { Relative } \\
\text { potency }\end{array}$ & $\begin{array}{l}\text { Half-lifet } \\
\text { hours }\end{array}$ & $\begin{array}{l}\text { Beta, } \\
\text { setectivity }\end{array}$ \\
\hline Atenolol & 1.0 & $6-9$ & + \\
Labetalol & 0.3 & $6-8$ & - \\
Metoprolol & 1.0 & $3-4$ & + \\
Nadolol & 1.0 & $14-24$ & - \\
Oxprenolol & $0.5-1.0$ & 2 & - \\
Pindolol & 6.0 & $3-4$ & - \\
Propranolol & 1.0 & $3.5-6$ & - \\
Timolol & 6.0 & $3-4$ & - \\
\hline
\end{tabular}

* Scc Table II for trade names.

†Oral administration. Information from Chung ${ }^{9}$ and Frishmun. ${ }^{10}$

It appears that the withdrawal syndrome associated with abrupt cessation of beta blocker therapy is in part related to the time course of drug elimination from the body, the time available for adjustment and the induction of new beta receptors. Therefore, withdrawal syndromes are likely to be most frequent in patients receiving agents with a short half-life (e.g., propranolol, Table III) and less common with agents with longer half-lives (e.g., nadolol).

Beta blocker therapy should normally be continued until the time of surgery, and resumed early following the operation. In some patients, substitution of a parenteral form will be necessary: both during and following surgery. "

\section{Vasodilators}

As summarized in Table IV, this category includes drugs with direct muscle relaxing properties, postsynaptic alpha, adrenergic antagonists, and calcium channel blocking agents. ${ }^{13}$ The greatest potential for drug interactions in anaesthesia appears to be associated with the calcium channel blockers. Although few clinical reports of such interactions have appeared, laboratory investigtion has identified potential interactions with inhalation anaesthetics, myocardial depressants, and neuromuscular blocking agents. Further investigation is required, but andesthetists should be aware of the possibility of interactions involving the calcium channel blockers.

\section{Angiotensin converting enzyme inhibitor}

Captopril inhibits angiotensin converting enzyme (ACE), which promotes the conversion of angioten- 
TABLE IV Vasodilators

\begin{tabular}{|c|c|c|}
\hline Generic/Trade names & Problems/Inieracitions & Comments \\
\hline \multicolumn{3}{|l|}{ Direct vascular dilators } \\
\hline Hydralazine/Apresoline*t & $\begin{array}{l}\text { (Usually used in combination with diuretic } \\
\text { and/or beta blocker duc to tachycardia and } \\
\text { increased renin levels produced by direct } \\
\text { hypotensive effect) }\end{array}$ & \\
\hline Minoxidil/Loniten*† & $\begin{array}{l}\text { Fotential added hypotensive effect with other } \\
\text { cardiovascular depressant agents }\end{array}$ & $\begin{array}{l}\text { Reduce titratcidoses of dcpressants. } \\
\text { Responsiveness to adrenergic agonists } \\
\text { (direct or indirect vasopressors) not } \\
\text { inpaired }\end{array}$ \\
\hline \multicolumn{3}{|l|}{ Alpha receptor antagonists } \\
\hline \multirow[t]{2}{*}{ Prazosin/Minipress** } & $\begin{array}{l}\text { (Produces decreased vascular resistance } \\
\text { through post-synaptic alpha, receptor } \\
\text { blockade) }\end{array}$ & $\begin{array}{l}\text { Reduceftitrate doses of agents used in } \\
\text { combination }\end{array}$ \\
\hline & $\begin{array}{l}\text { Predicted added hypotensive effect of } \\
\text { anaesthetic ugents (inhaled and injected) } \\
\text { and techniques (e.g., spinal anaesthesia) }\end{array}$ & $\begin{array}{l}\text { Use reduced/titraled doses of anaesthetics. } \\
\text { Treat hypotension in conventional manner }\end{array}$ \\
\hline \multirow{8}{*}{$\begin{array}{l}\text { Calcium channel blockers } \\
\text { Verapamil/isoptin* } \dagger \text {, Calan } \\
\text { Njfedipine/Aldalat, }{ }^{\dagger} \text { Procardia* } \\
\text { Diltiazem/Cardizem }{ }^{* \dagger}\end{array}$} & & \\
\hline & (Nifedipine and diltazem are used primasily & \\
\hline & for their anti-anginal effects; verapamil as & \\
\hline & $\begin{array}{l}\text { an anti-arrhythmic and anti-anginal agent. } \\
\text { Use as anti-hypertensives ("approved" and } \\
\text { otherwise) is becoming more frequent) }\end{array}$ & \\
\hline & $\begin{array}{l}\text { Reduce MAC for halothane in dogs } \\
\text { (verapamil) }\end{array}$ & $\begin{array}{l}\text { Mechanism unknown. Clinical information } \\
\text { pending }\end{array}$ \\
\hline & $\begin{array}{l}\text { Enhanced hypotensive effect of anaesthetics } \\
\text { (inhaled and injected) }\end{array}$ & $\begin{array}{l}\text { Added negative inotropic effect. Use } \\
\text { combination with caution }\end{array}$ \\
\hline & $\begin{array}{l}\text { Potentiation of pancuronium and succinyl- } \\
\text { choline neuromuscular block }{ }^{14} \\
\text { (verapamil-animals) }\end{array}$ & Clinical significance not yet established \\
\hline & $\begin{array}{l}\text { Acule respiratory failure following }] \mathrm{V} \\
\text { verapamil in a patient with Duchenne's } \\
\text { muscular dystrophy }\end{array}$ & $\begin{array}{l}\text { Use with caution in presence of muscular or } \\
\text { neuromuscular disorders. More } \\
\text { information needed }\end{array}$ \\
\hline
\end{tabular}

*USA.

†Canada.

TABLE $V$ Angiotenșin converting enzyme inhibitor

\begin{tabular}{lll}
\hline GenericiTrade names & Problems/lmteractions & Comments \\
\hline Captopril/Capoten*t & $\begin{array}{c}\text { (Mechanism of action not fully establistred. } \\
\text { Interferes with conversion of anglotensin I to } \\
\text { angiotensin II. Antihypertensive effect seen even } \\
\text { in presence of normal or low renin levels) } \\
\text { Additive hypotensive effects with other } \\
\text { antihypertensives } \\
\text { Predicted limitation of angiotensin mediatcd } \\
\text { responsc to hypovolemia, or hypotension due to } \\
\text { anaesthetics or other agents }\end{array}$ & $\begin{array}{c}\text { Significance not established. Treat hypotension in } \\
\text { conventional mannet }\end{array}$ \\
\hline
\end{tabular}

*USA.

tCanada: 
sin I to angiotensin II (angiotensin I is formed from a precursor, in the presence of renin). Angiotensin II is an endogenous vasoconstrictor and also stimulates secretion of aldosterone from the adrenal cortex. However, the antihypertensive effect of captopril has not been clearly related to its ability to inhibit ACE. A discussion of the postulated mechanisms of action of captopril is beyond the scope of this review.

Table $\mathrm{V}$ summarizes the predicted effects of captopril therapy on angiotensin-mediated responses to hypovolemia and/or hypotension. While the clinical significance of these predictions has not been established, caution is advised.

\section{Conclusion}

The perioperative period, and most particularly the anaesthetic itself, creates an interface between chronic and acute drug therapy. As the primary managers of this interface, anaesthetists must be aware of the actions and interactions of varied and complex medications.

Antihypertensive agents present a significant potential for drug interactions during anaesthesia. With the exception of monoamine inhibitors, antihypertensives should be continucd up to the time of surgery. Safe anaesthetic management requires anticipation of drug intcractions, recognition of their effects, and knowledge of appropriate corrective therapy. This review has provided information and guidelines which help to accommodatc these needs.

\section{References}

1 Reid D, Aylmer A. Hypertension in Anaesthesia. Can Anaesth Soc J 1984; 31: 222-30.

2 Prys-Roberts $C$. Chronic Antihypertensive Therapy. Chap 15, pp. 345-62 in: Kaplan JA, Edilor. Cardiac Anesthesia, Volume 2, Cardiovascular Pharmacology. Grune \& Stratton, New York, 1983.

3 Weir $P C$, Chung FF. Anacsthesia for patients with chronic renal disease. Can Anaesth Soc J 1984; 31 : 468-80.

4 Merin RG, Bastron RD. Diuretics. Chap 11, pp. 145-62. In: Smith NT, Miller RD, Corbascio AN. Drug luteractions in Anesthesia. Lea \& Febiger Philadelphia: 1981

5 Hoffman BB, Lefkowitz RJ. Alpha-adrenergic receptor subtypes. N Engl J Med 1980; 302: 1390-6.
6 Langer $S Z$. Presynaptic receptors and modulation of neurotransmission: Pharmacological implicatiuns and therapeutic relevance. Trends Neurosi 1980;3: $110-2$.

7 Compendium of Pharmaceuticals and Spccialtics. Canadian Pharmaceutical Assaciation, Ottawa, Ed. 19, 1984. p. 169.

8 Wong KC. Sympathomimetic Drugs. Chap 6, pp. 55-82. In: Smith NT, Miller RD. Corbascio AN. Drug Interactions in Anesthesia. Lea \& Febiger Philadelpnia, 1981.

9 Chang $D C$, Laschuk MJ. The new beta-adrenergic antagonists. Can Anaesth Soc J 1984; 31: 430-3.

10 Frishman WH. $\beta$-adrenoceptor antagonists: New drugs and new indications. N Engl J Med 1981, 305: 500-6.

11 Slogoff S. Beta-adrenergic blockers. Chap 8, pp 181-208. Ir:Kaplan JA, Editor. Cardiac Anesthesia, Volume 2, Cardiovascular Pharmacology. Grune \& Stratton, New York, 1983

12 Lowenstein E. Beta-adrenergic blockers, Chap 7 , pp. 83-101. In: Smith NT, Miller RD, Carbascio AN Drug Interactions in Anesthesia. Lea \& Febiger Philadelphia, 1981.

13 Reves $J G_{1}$ Kissin 1 , Well WA, Tosone S. Calcium entry blockers: Uses and implications for the anesthesiologist. Anesthesiology 1982; 57: 504-18.

14 Durant NN, Nguyen N, Katz RL. Potentiation of neuromuscular blockade by verapamil. Anesthesiology 1984; 60: 298-303.

15 Zalman F, Perloff JK, Duram NN, Campion DS. Acute respiratory failure following intravenous verapamil in Duchenne's muscular dystrophy. Am Heart J 1983, 105: 510-I.

16 The Medical Letter Handbook of Drug Interactions. The Medical Letter. New Rochelle NY, 1983.

17 Martin EW. Drug Interactions Index 1978/79. Lippincott, Philadelphia. 